\title{
Balance Sheet Method Assessment for Nitrogen Fertilization in Winter Wheat: II. Alternative Strategies Using the CropSyst Simulation Model
}

\author{
Gianni Bellocchi ${ }^{*}$, Marcello Donatelli ${ }^{1}$, Mario Monotti², Giuseppe Carnevali ${ }^{3}$, \\ Maria Corbellini ${ }^{4}$, Diego Scudellari ${ }^{5}$ \\ ${ }^{1}$ Consiglio per la Ricerca e la Sperimentazione in Agricoltura, Istituto Sperimentale \\ per le Colture Industriali, Bologna, Italy \\ ${ }^{2}$ Dipartimento di Scienze Agroambientali e della Produzione Vegetale, sezione di Agronomia \\ e Coltivazioni Erbacee, Università di Perugia, Italy \\ ${ }^{3}$ Regione Emilia-Romagna, Bologna, Italy \\ ${ }^{4}$ Consiglio per la Ricerca e la Sperimentazione in Agricoltura, Istituto Sperimentale per la Cerealicoltura, \\ Sant'Angelo Lodigiano (Lodi), Italy \\ ${ }^{5}$ Centro Ricerche Produzioni Vegetali, Imola (Bologna), Italy
}

Received: 26 October 2004. Accepted: 17 March 2006

\begin{abstract}
It is important, both for farmer profit and for the environment, to correctly dose fertilizer nitrogen (N) for winter wheat growth. Balance-sheet methods are often used to calculate the recommended dose of $\mathrm{N}$ fertilizer. Other methods are based on the dynamic simulation of cropping systems. Aim of the work was to evaluate the balance-sheet method set up by the Region Emilia-Romagna (DPI), by comparing it with the cropping systems simulation model CropSyst (CS), and with an approach based on fixed supplies of $\mathrm{N}$ (T). A 3-year trial was structured as a series of $\mathrm{N}$ fertility regimes at 3 sites (Papiano di Marsciano, Ravenna, San Pancrazio). The N-regimes were generated at each site-year as separate trials in which $3 \mathrm{~N}$ rates were applied: N1 (DPI), N2 (DPI+50 kg ha-1 $\mathrm{N}$ at spike initiation), N3 (DPI $+50 \mathrm{~kg} \mathrm{ha}^{-1} \mathrm{~N}$ at early booting). Above ground biomass and soil data $\left(\mathrm{NO}_{3}-\mathrm{N}\right.$ and water) were sampled and used to calibrate CS. Doses of fertilizer N were calculated by both DPI and CS for winter wheat included in three typical rotations for Central and Northern Italy. Both these methods and method $\mathrm{T}$ were simulated at each site over 50 years, by using daily generated weather data. The long-term simulation allowed evaluating such alternative fertilization strategies. DPI and CS estimated comparable crop yields and N leached amounts, and both resulted better than T. Minor risk of leaching emerged for all N doses. The N2 and N3 rates allowed slightly higher crop yields than N1.
\end{abstract}

Key-words: balance-sheet method, CropSyst, leaching, nitrogen fertilization, winter wheat.

\section{Introduction}

The amount of fertilizer nitrogen $(\mathrm{N})$ applied to a crop has important repercussions both for the farmer profit and for the environment (Spiertz, 2002). Environmental constraints are forcing farmers in Western Europe to be increasingly precise in determining the rate and date of nitrogen fertilizer application to crops. Leaching is the major route by which nitrate enters ground and surface waters, while denitrification and volatilization are significant sources of $\mathrm{N}_{2} \mathrm{O}$, an important greenhouse gas. Environmental concerns have become pressing after the European Directive 91/676 (nitrate directive) was published, which calls for the identification of pollution-sensitive zones and for strict control of fertilizer $\mathrm{N}$ use within those zones. This has led to a series of local initiatives with the objective of defining environmentally sound farming practices in each region (Ziegler et al., 1996;

\footnotetext{
* Corresponding Author: Tel.: +39 0332 786798; Fax: +39 0332 785483. E-mail address: gianni.bellocchi@jrc.it.
} 
Spiertz, 2002; Vanden Auweele and Vandendriessche, 2002).

Achieving synchrony between $\mathrm{N}$ supply and crop demand without excess or deficiency is the key to optimizing trade-offs amongst yield and environmental protection. Developing effective strategies to meet this challenge requires quantitative understanding of current levels of $\mathrm{N}$ use efficiency and losses in cropping systems, and the biophysical controls on these factors from adoption of improved management practices (MacDonald et al., 1989; Powlson et al., 1992; Strong, 1995; Recous et al., 1997). Fertilizer recommendations are embodied in decision rules, which prescribe a recommended nitrogen dose as a function of site-year characteristics available at the time the fertilizer decision is made. Many different decision rules can be and have been proposed (Rèmy and Hébert, 1977; Wehrmann et al., 1988; de Willigen, 1991; Jeuffroy and Recous, 1999; Thorup-Kristensen, 2002), and it is important to be able to choose the most appropriate.

A family of methods for calculating $\mathrm{N}$ fertilizer requirements includes the so-called balance-sheet methods, based on a vector of crop, climate, and site-year characteristics. Such methods are widely used in Europe (e.g., Machet and Dubrulle, 1990; ITCF, 1996; Meynard et al., 1997). The Region Emilia-Romagna set up a balance-sheet method (Disciplinare Produzione Integrata, hereafter designated as DPI) for estimating the winter wheat fertilizer $\mathrm{N}$ requirements, based on the main but effective factors affecting crop nutrition (Carnevali and Sarno, 1998; AA.VV., 2000; Carnevali et al., 2000). This is a static method which gives, in its original outline, the amount of fertilizer $\mathrm{N}$ to be supplied at spike initiation. According to manuscript I, additional nitrogen supplies are suggested, even applied in two dressings (second application at beginning of booting), especially for great strength and high bread-making quality's cultivars. This arises environmental concerns, as extra-N supplies may at times give unacceptable risks for the environment.

A second family of decision rules is based on dynamic simulation modelling of the cropping systems (Addiscott et al., 1991; Kerserbaum and Richter, 1991; Otter-Nacke and Khulmann, 1991). A crop growth estimator, simulating crop biomass accumulation with variations of climate/soil variables and management options, is at the core of cropping systems models. Dynamic models can be used to schedule $\mathrm{N}$ fertilization of field crops by simulation-based decision rules (Meynard et al., 2002), as they estimate soil profile nitrogen and crop uptake including the entire soil depth explored by roots, and using a daily frequency. Some cropping systems models make available automatic options for optimum scheduling of nitrogen fertilization, while providing insight into the system. This is the case of CropSyst (Stöckle et al., 2003), which was used in this work.

The choice of decision rules can have important repercussions on the recommended amount of $\mathrm{N}$ fertilizer. Evaluating different methods poses some issues on how judge them. Traditionally, this has been done by experimental trials performed at different sites over a few growing seasons (Magnickij, 1973). These studies are generally limited in scope and do not account for long-term effects (exceptional and/or cyclical weather variability) as needed for probabilistic assessments and decision making. The assessment of the impact of recommended $\mathrm{N}$ rates from alternative methods on crop productivity and the environment in the long time is one case where conventional experimentation is of limited use without the complement of simulation-based tools. In particular, the information gathered from field trials may be used in conjunction with computer simulation to obtain a more complete understanding of the problem and extrapolate findings in time. Cropping systems models are suitable to account for uncertainties in the weather variability when coupled to weather generators.

Aim of this paper was to evaluate, by means of a long-term simulation analysis, the static model set up for winter wheat by the Region Emilia-Romagna (DPI), comparing it with the CropSyst automatic $\mathrm{N}$ fertilization option and a conventional $\mathrm{N}$ management.

\section{Materials and methods}

\subsection{Fertilizer nitrogen requirement}

An empiric and static method developed by the Region Emilia-Romagna was used for the calculation of $\mathrm{N}$ fertilizer. The method, designated hereafter as DPI, has been described in manu- 


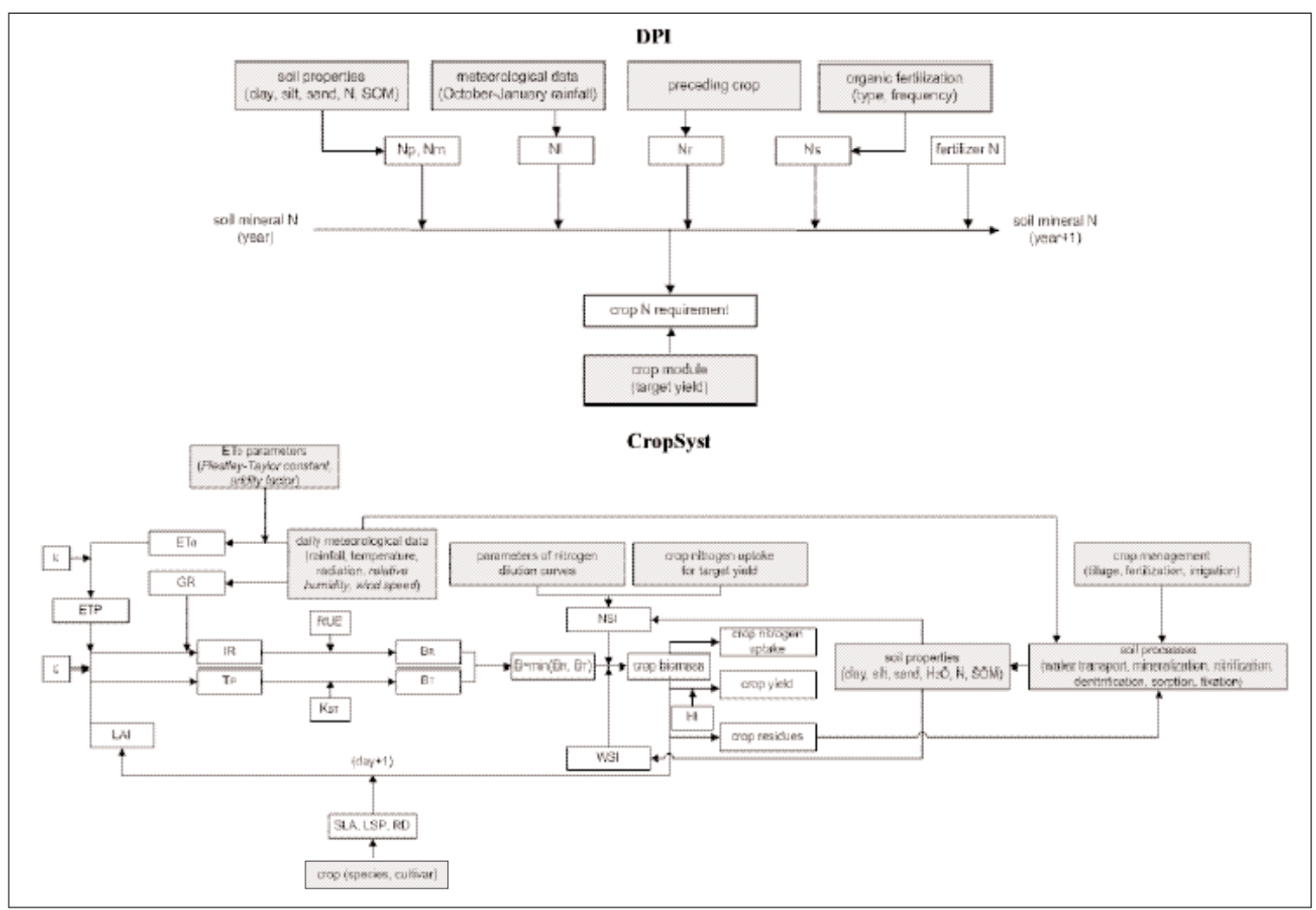

Figure 1. Diagrams of the DPI balance-sheet and CropSyst methods of nitrogen requirement. N: total soil nitrogen; SOM: soil organic matter; Np: available nitrogen at sowing date; Nm: mineralized nitrogen from soil organic matter; Nl: nitrogen lost by leaching; Nr: nitrogen from the preceding crop; Ns: nitrogen from organic fertilization; $\mathrm{ET}_{0}$ : reference crop evapotranspiration; k: evapotranspiration crop coefficient; ETP: crop potential evapotranspiration; GR: global radiation; $\varepsilon$ : extinction coefficient; IR: intercepted radiation; $\mathrm{T}_{\mathrm{p}}$ : potential transpiration; LAI: leaf area index; SLA: specific leaf area; LSP: leaf/stem partition coefficient; RD: root depth; RUE: radiation use efficiency; $\mathrm{K}_{\mathrm{BT}}$ : biomass-transpiration coefficient; $\mathrm{B}_{\mathrm{R}}$ : radiation-limited crop biomass; $\mathrm{B}_{\mathrm{T}}$ : water-limited crop biomass; $\mathrm{B}$ : potential crop biomass; NSI: nitrogen stress index; WSI: water stress index; HI: harvest index; boxes in grey: sub-model inputs; italicized words: optional inputs (ET ${ }_{0}$ Penman-Monteith equation is applied if optional meteorological variables are available, Priestley-Taylor equation otherwise).

script I and is based on a simplified nitrogen budget over the growing season (top graph of Figure 1).

CropSyst (version 3.03.12; Stöckle et al., 2003), a cropping systems simulation model with crop growth and water and $\mathrm{N}$ balance capabilities (bottom graph of Figure 1), was also used to schedule $\mathrm{N}$ fertilizations, based on crop $\mathrm{N}$ requirements corresponding to known yield expectations and $\mathrm{N}$ budgeting simulation (Donatelli and Stöckle, 2000). The crop sub-model simulates the daily $\mathrm{N}$ requirements of the crop, according to water- and radiation-limited analysis, and from the changes in the critical $\mathrm{N}$ content of the aerial parts of the crop (Justes et al., 1994). The mineral $\mathrm{N}$ budget in CropSyst includes separate budgets for nitrate and ammo- nium. Processes include $\mathrm{N}$ transformations, ammonium sorption, symbiotic $\mathrm{N}$ fixation (when required), crop $\mathrm{N}$ demand and crop $\mathrm{N}$ uptake. Nitrogen transformations (net mineralization, nitrification, and denitrification) and ammonium sorption follow the approach presented by Stöckle and Campbell (1989). Due to its ability to integrate soil water and $\mathrm{N}$ budgets and weather variables to produce realistic simulations of crop growth and yield, the model was found suitable to meet the requirements of this study.

\subsection{Field experiments}

2.2.1 Sites, years and management-regimes. We refer the interested reader to manuscript I for details on field trials. Crop and soil data for the 
Table 1. Initial soil characteristics at the three sites.

\begin{tabular}{|c|c|c|c|c|c|c|}
\hline \multirow[t]{2}{*}{ Soil variable } & \multicolumn{5}{|c|}{ Soil depth (m) } & \multirow[b]{2}{*}{$1.0-1.2$} \\
\hline & $0.0-0.2$ & $0.2-0.4$ & $0.4-0.6$ & $0.6-0.8$ & $0.8-1.0$ & \\
\hline \multicolumn{7}{|c|}{ Papiano di M. (09/12/1997) } \\
\hline Sand $(\%)$ & 12.1 & 14.0 & 9.3 & 5.6 & 4.4 & 10.9 \\
\hline Silt (\%) & 48.9 & 47.4 & 48.3 & 53.5 & 55.0 & 55.6 \\
\hline Clay (\%) & 39.0 & 38.6 & 42.4 & 41.0 & 40.6 & 33.5 \\
\hline $\operatorname{SOM}(\%)$ & 1.6 & 1.7 & 1.6 & 1.2 & 1.0 & 0.7 \\
\hline Total N (\%o) & 1.6 & 1.6 & 2.8 & 1.8 & 1.1 & 1.1 \\
\hline $\mathrm{NO}_{3}-\mathrm{N}\left(\mathrm{mg} \mathrm{kg}^{-1}\right)$ & 3.9 & 3.4 & 4.0 & 2.6 & 1.4 & 2.8 \\
\hline \multicolumn{7}{|c|}{ Ravenna (03/11/1997) } \\
\hline Sand $(\%)$ & 9.7 & 9.3 & 8.5 & 3.0 & 7.8 & 9.0 \\
\hline Silt (\%) & 64.3 & 64.7 & 64.8 & 68.2 & 66.0 & 71.3 \\
\hline Clay (\%) & 26.0 & 26.0 & 26.7 & 28.8 & 26.2 & 19.7 \\
\hline SOM (\%) & 1.6 & 1.6 & 1.4 & 1.2 & 0.9 & 0.7 \\
\hline Total N (\%o) & $1.1^{*}$ & & & & & \\
\hline $\mathrm{NO}_{3}-\mathrm{N}\left(\mathrm{mg} \mathrm{kg}^{-1}\right)$ & 3.3 & 3.2 & 12.3 & 1.1 & 0.6 & 10.5 \\
\hline \multicolumn{7}{|c|}{ San Pancrazio (31/10/1997) } \\
\hline Sand $(\%)$ & 20.7 & 16.8 & 13.3 & 14.5 & 27.3 & 11.5 \\
\hline Silt (\%) & 40.3 & 41.0 & 45.2 & 44.0 & 29.0 & 49.5 \\
\hline Clay (\%) & 39.0 & 42.2 & 41.5 & 41.5 & 43.7 & 39.0 \\
\hline SOM (\%) & 1.8 & 2.00 & 1.4 & 1.2 & 1.0 & 0.8 \\
\hline Total N (\%o) & $1.6^{*}$ & & & & & \\
\hline $\mathrm{NO}_{3}-\mathrm{N}\left(\mathrm{mg} \mathrm{kg}^{-1}\right)$ & 4.0 & 4.7 & 6.8 & 28.2 & 7.3 & 1.7 \\
\hline
\end{tabular}

* Average value across all layers of the soil profile.

modelling approach presented in this study were collected on cultivars Bolero and Pascal only. After a preliminary analysis performed at all locations, a full modelling study was carried out at three sites: Papiano di Marsciano (Region Umbria, province of Perugia, lat. $42.57 \mathrm{~N}$, long. 12.22 E), Ravenna (Region Emilia-Romagna, lat. $44.00 \mathrm{~N}$; long. 11.90 E), San Pancrazio (Region Emilia-Romagna, province of Parma, lat. $44.50 \mathrm{~N}$, long. $10.28 \mathrm{E}$ ).

Initial soil characteristics are reported in Table 1. Soils are regarded as clay at Papiano di Marsciano and San Pancrazio, and loam at Ravenna. Weather data obtained from weather stations located near the experimental sites were used as a characterization of the weather conditions at each of the nine site-year combinations sampled in this study. In summary, the three locations are characterized by fairly similar climatic conditions, i.e. warm humid summers, with maximum air temperature at times higher than $35^{\circ} \mathrm{C}$, maximum relative humidity often higher than $95 \%$, and rainfall mostly concentrated in spring and autumn. Differences in the precipitation patterns are shown in Figure 2. Within each site-year combination the man- agement variables planting time, fertilizer $\mathrm{N}$ application, and preceding crop were manipulated to create a number of different managementregime treatments. Management-regime treatments for each cultivar differed among the nine site-year combinations tested, giving a total of 81 trials (Table 2).

2.2.2 Soil and crop samplings. Soil water content $\left(\mathrm{m}^{3} \mathrm{~m}^{-3}\right)$ was periodically measured in the upper $0-1.2 \mathrm{~m}$ using the gravimetric method. Soil $\mathrm{NO}_{3}-\mathrm{N}$ content $\left(\mathrm{kg} \mathrm{N}^{-1}\right)$ was sampled at 0 $1.2 \mathrm{~m}$ depth in the same period by ion selective electrode method.

Crop sampling regarded periodical measures of above ground dry matter $\left(\mathrm{kg} \mathrm{ha}^{-1}\right)$, above ground nitrogen uptake $\left(\mathrm{kg} \mathrm{ha}^{-1}\right)$, grain yield $(\mathrm{kg}$ $\left.\mathrm{ha}^{-1}\right)$ and identification of the main phenological phases (seedling emergence, peak of leaf area index, start of flowering, physiological maturity).

\subsection{The simulation study}

2.3.1 Model parameters. Winter wheat parameters required by CropSyst were set based on typical field observations, or were taken from 
Table 2. Experimental layout.

\begin{tabular}{|c|c|c|c|c|c|c|}
\hline \multirow[b]{2}{*}{ Site } & \multirow[b]{2}{*}{ Preceding crop } & \multirow[b]{2}{*}{ Sowing date } & \multicolumn{4}{|c|}{$\mathrm{N}$ schedule $\left(\mathrm{kg} \mathrm{ha}^{-1}\right)$} \\
\hline & & & Date & N1 rate & $\mathrm{N} 2$ rate & $\mathrm{N} 3$ rate \\
\hline \multirow{8}{*}{ Papiano di Marsciano } & \multirow{2}{*}{ Sorghum } & \multirow{2}{*}{ 09/12/1997 } & $02 / 03 / 1998$ & 100 & 150 & 100 \\
\hline & & & $23 / 03 / 1998$ & 50 & 50 & 100 \\
\hline & \multirow{2}{*}{ Sunflower } & \multirow{2}{*}{ 10/11/1998 } & 09/03/1999 & 85 & 135 & 85 \\
\hline & & & $01 / 04 / 1999$ & 44 & 44 & 94 \\
\hline & \multirow{2}{*}{ Sunflower } & \multirow{2}{*}{ 30/11/1999 } & $09 / 03 / 2000$ & 87 & 137 & 87 \\
\hline & & & $30 / 03 / 2000$ & 43 & 43 & 93 \\
\hline & \multirow{2}{*}{ Soybean } & \multirow{2}{*}{ 03/11/1997 } & $16 / 03 / 1998$ & 80 & 130 & 80 \\
\hline & & & 20/04/1998 & 40 & 40 & 90 \\
\hline \multirow[t]{6}{*}{ Ravenna } & \multirow{2}{*}{ Sugar beet } & \multirow{2}{*}{ 28/10/1998 } & $17 / 03 / 1999$ & 78 & 128 & 78 \\
\hline & & & $15 / 04 / 1999$ & - & - & 50 \\
\hline & \multirow{2}{*}{ Tomato } & \multirow{2}{*}{ 29/10/1999 } & $28 / 02 / 2000$ & 40 & 40 & 40 \\
\hline & & & $24 / 03 / 2000$ & 78 & 128 & 78 \\
\hline & \multirow{2}{*}{ Sugar beet } & \multirow{2}{*}{ 18/11/1997 } & $21 / 04 / 2000$ & - & - & 50 \\
\hline & & & $27 / 03 / 1998$ & 80 & 130 & 80 \\
\hline \multirow[t]{5}{*}{ San Pancrazio } & \multirow{2}{*}{ Sugar beet } & \multirow{2}{*}{$30 / 10 / 1998$} & $17 / 04 / 1998$ & - & - & 50 \\
\hline & & & $24 / 03 / 1999$ & 63 & 113 & 63 \\
\hline & \multirow{3}{*}{ Sugar beet } & \multirow{3}{*}{ 01/11/1999 } & 20/04/1999 & - & - & 50 \\
\hline & & & $06 / 04 / 2000$ & 76 & 126 & 76 \\
\hline & & & $03 / 05 / 2000$ & - & - & 50 \\
\hline
\end{tabular}

the manual or other literature sources. A few parameters that tend to fluctuate among cultivars (e.g., above ground biomass-transpiration
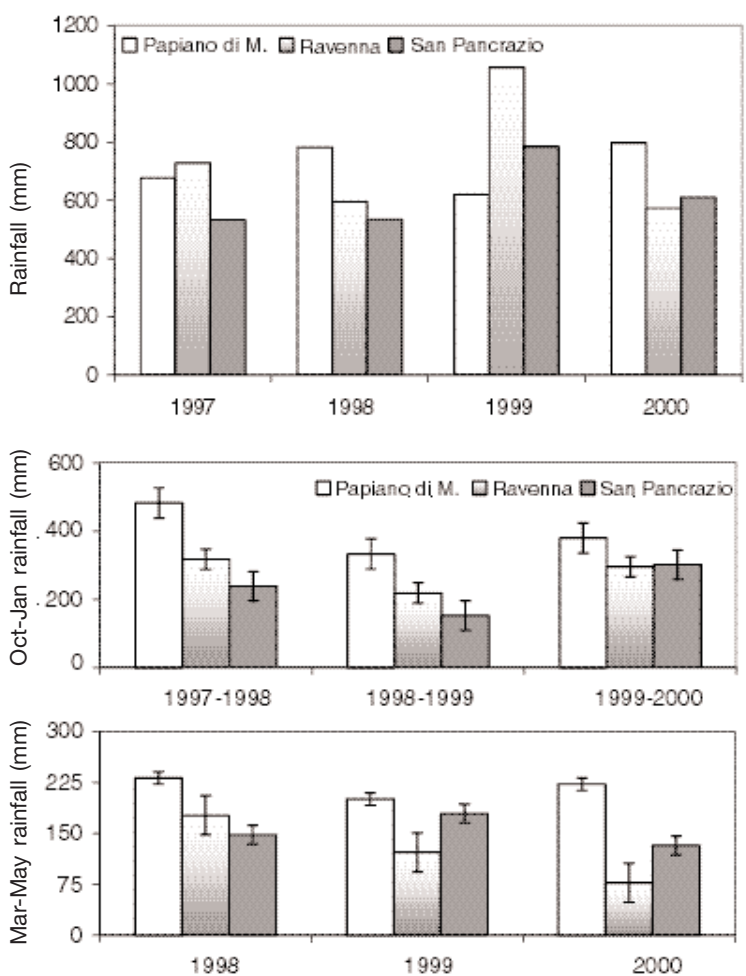

Figure 2. Annual rainfall amount $(\mathrm{mm})$, rainfall amount in the period October-January, and rainfall amount in the period March-May registered at three locations during four years. coefficient) were calibrated to match selected data with model outputs. Field data corresponding to 3-year trials done in all locations were used for calibration. Crop phenology observed in the first growing season was the basis for determining the thermal time requirement for each phenological stage. Harvest dates for winter wheat occurred through July at all sites with some variations from season to season.

Parameters for potato, sugar beet and sunflower were extracted from the manual or other sources (Donatelli et al., personal communications). Weather parameters were extracted from 10-15 years of weather records (daily rainfall, minimum/maximum air temperatures, and daily incident solar radiation) and used to generate 50 years of daily records by using the weather generator ClimGen (version 4.01.05, Stöckle et al., 2001).

2.3.2 Long-term simulations. Fifty years of continuous cropping were simulated at each location. Table 3 gives the details of the $\mathrm{N}$ management scenarios used in this work. Three rotations, including winter wheat, that are traditionally performed in the study sites were used for long-term simulations: sugar beet-winter wheat (sb-ww), sugar beet-winter wheat-potato-winter wheat (sb-ww-p-ww), sunflower-winter wheat (sf-ww). The scenarios cover both DPI and CS strategies, according to three rate-spreading 
Table 3. Nitrogen management scenarios used in the simulation study.

\begin{tabular}{|c|c|c|c|c|c|}
\hline \multirow{2}{*}{ Variable } & \multirow{2}{*}{ Option } & \multicolumn{4}{|c|}{ Crops } \\
\hline & & Winter wheat & Sugar beet & Potato & Sunflower \\
\hline \multirow[t]{3}{*}{ Rotation } & sb-ww & $\mathrm{x}$ & $\mathrm{x}$ & - & - \\
\hline & sb-ww-p-ww & $\mathrm{x}$ & $\mathrm{x}$ & $\mathrm{x}$ & $\mathrm{x}$ \\
\hline & sf-ww & $\mathrm{x}$ & - & - & $\mathrm{x}$ \\
\hline \multirow[t]{7}{*}{ Fertilization strategy } & DPI & $\mathrm{x}$ & - & - & - \\
\hline & & $\mathrm{x}$ & - & - & - \\
\hline & & $\mathrm{x}$ & - & - & - \\
\hline & CS & $\mathrm{x}$ & - & - & - \\
\hline & & $\mathrm{x}$ & - & - & - \\
\hline & & $\mathrm{x}$ & - & - & - \\
\hline & conventional & $\mathrm{x}$ & $\mathrm{x}$ & $\mathrm{x}$ & $\mathrm{x}$ \\
\hline \multirow{3}{*}{ Fertilizer $\mathrm{N}$ rate $\left(\mathrm{kg} \mathrm{ha}^{-1}\right)$} & $\mathrm{N} 1$ & DPI & - & - & - \\
\hline & $\mathrm{N} 2, \mathrm{~N} 3$ & $\mathrm{DPI}+50$ & - & - & - \\
\hline & conventional & 220 & 100 & $100+50$ & 120 \\
\hline \multirow{4}{*}{ Fertilizer spreading time } & $\mathrm{N} 1, \mathrm{~N} 2$ & February 28 & - & - & - \\
\hline & $\mathrm{N} 3$ & February 28 & & & \\
\hline & & March 21 & - & - & - \\
\hline & conventional & February 28 & April 15 & $\begin{array}{c}\text { March } 10 \\
\text { May } 10\end{array}$ & March 2 \\
\hline
\end{tabular}

time combinations (N1, N2, N3). The CS strategies were achieved by setting $\mathrm{N}$ fertilization parameters so as to approximate, in the long-term average, the $\mathrm{N} 1$ and $\mathrm{N} 2 / \mathrm{N} 3$ rates derived from DPI. A third option ("traditional", hereafter indicated with $\mathrm{T}$ ) was also run, by using a fixed rate of $\mathrm{N}$ every year, i.e. $220 \mathrm{~kg} \mathrm{ha}^{-1}$, assumed to represent a conventional $\mathrm{N}$ management. For crops other than winter wheat, sowing dates, fertilizer $\mathrm{N}$ rates and application dates were set according to typical agricultural practices of Central and Northern Italy. The crops were conducted under rainfed conditions. Gaseous losses were negligible, as expected from wheat systems where fertilizer $\mathrm{N}$ is incorporated into the soil and ponding is not likely to occur.

Simulations for the 50 years were performed more times, in order to obtain simulated growth for each crop in one year of the study period in the rotation. For instance, simulation of the rotation sb-ww-p-ww was performed four times: the first starting with sugar beet, the second with winter wheat preceding potato, the third with potato, and the fourth with winter wheat preceding sugar beet. Fifty-six simulations were performed at each location with CropSyst using an implementation (Steiner et al., 1991) of the Priestley-Taylor model (Priestley and Taylor, 1972) for calculating evapotranspiration and the finite difference approach (Richards, 1931) for soil water transport. Each of the combinations was simulated for 50 years without reinitialising the state variables, thus allowing the state of the soil to evolve from season to season through the simulation. This allowed assessing the long-term impact on system performance after many consecutive simulated crop seasons. The initial soil water content of the soil profile (1.2 $\mathrm{m}$ depth) at the beginning of each 50-year simulation was set equal to $2 / 3$ of the estimated field capacity. The initial nitrogen content of the soil profile was set at about $0.1 \%$ of total $\mathrm{N}$, as $\mathrm{NO}_{3}-\mathrm{N}$. Nitrogen from crop residues was accounted for by incorporating the residues through tillage, and later biologically decaying and transforming these residues to release mineral $\mathrm{N}$ and add to the stable organic matter.

\section{Results}

\subsection{Experimental observations and simulations}

Long-term average rainfall at the three sites was estimated with ClimGen: $616 \mathrm{~mm}$ at San Pancrazio, $670 \mathrm{~mm}$ at Ravenna, and $720 \mathrm{~mm}$ at Papiano di Marsciano. Figure 2 (top graph) indicates the distribution of the rainfall amounts registered at the three sites in the years investigated. Average rainfall at the Emilia-Romagna sites was much above ( $+69 \mathrm{~mm}$ at Ravenna) or below (-114 mm at San Pancrazio) long-term average, while average rainfall at Papiano di 

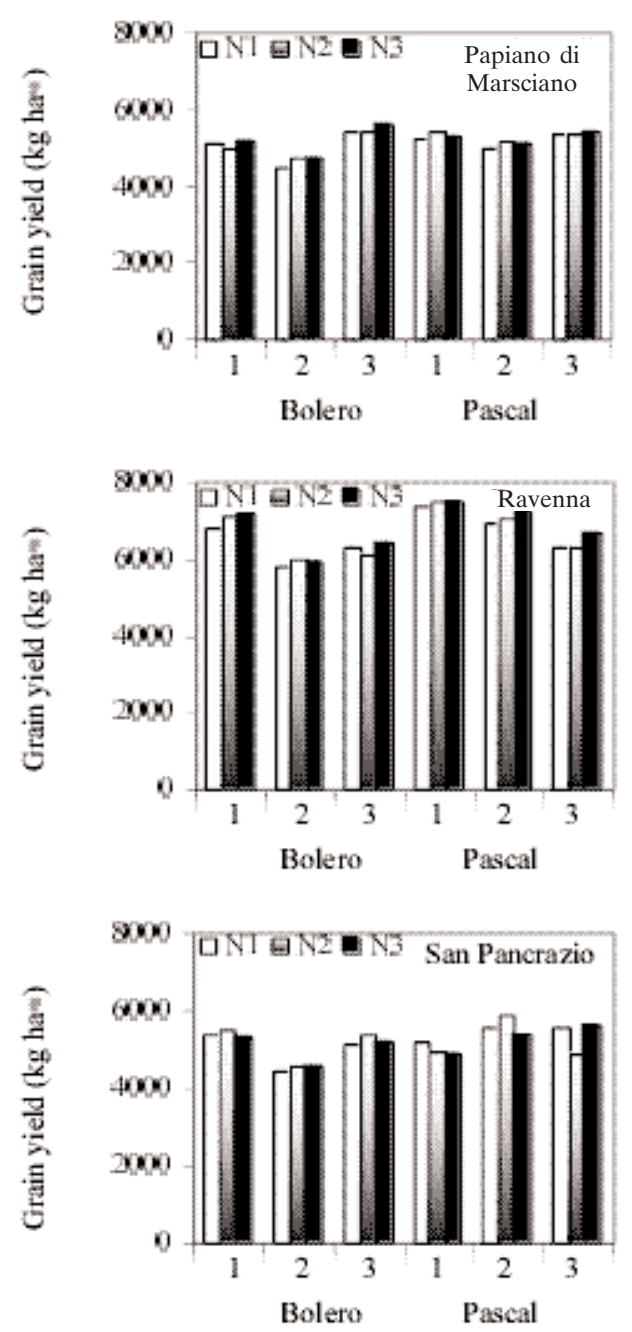

Figure 3. Grain yield $\left(\mathrm{kg} \mathrm{ha}^{-1}\right)$ of two winter wheat cultivars (Bolero, Pascal) from $\mathrm{N}$ fertilization trials conducted at three sites (Papiano di Marsciano, Ravenna, San Pancrazio) during three growing seasons (1: 1997-1998, 2: 1998-1999, 3: 1999-2000).

Marsciano stayed closer onto long-term average $(-40 \mathrm{~mm})$. Bottom graph of Figure 2 reports rainfall pattern (average and standard error), as registered at each location in the months October to January (i.e., the relevant period for the calculation of fertilizer N) and March to May (i.e., including the $\mathrm{N}$ application period) during the 3-season trials. Total rainfall in the months October to January reached $38-55 \%$ of the annual precipitation, whereas it reached $17-29 \%$ in the months March to May. There was a greater amount of rainfall at Papiano di Marsciano than at the other locations over the months October to January (about $400 \mathrm{~mm}$ in average, against 280 and 230 of Ravenna and San Pancrazio, respectively). Year-to-year variability at Papiano di Marsciano was also higher in October-January (standard error equal to $44.3 \mathrm{~mm}$ ), while it was the smallest on yearly basis (as derived from the top graph).

Results from the $\mathrm{N}$ fertilizer trials showed some differences in mean grain yield among the three sites and years (Figure 3) but, in general, mean values agreed with those recorded in the official national trials (Perenzin et al., 1998, 1999, 2000). Ravenna showed major production potentialities, with about $6600 \mathrm{~kg} \mathrm{ha}^{-1}$ of grain yield in average at $\mathrm{N}$ rate equal to $\mathrm{N} 1$, against about $5000 \mathrm{~kg} \mathrm{ha}^{-1}$ and $5200 \mathrm{~kg} \mathrm{ha}^{-1}$ registered at Papiano di Marsciano and San Pancrazio, respectively. Grain yields observed with $\mathrm{N} 1$ at $\mathrm{Pa}-$ piano di Marsciano and Ravenna were substantially in line with the prescribed yield for DPI computations $\left(5220 \mathrm{~kg} \mathrm{ha}^{-1}\right.$, equal to $6000 \mathrm{~kg} \mathrm{ha}^{-1}$ with $13 \%$ standard humidity, at Papiano di Marsciano; $6090 \mathrm{~kg} \mathrm{ha}^{-1}$, equal to $7000 \mathrm{~kg} \mathrm{ha}^{-1}$ with $13 \%$ standard humidity, at Ravenna), whilst crop yield at San Pancrazio was much below the advised value $\left(6090 \mathrm{~kg} \mathrm{ha}^{-1}\right.$, equal to $7000 \mathrm{~kg} \mathrm{ha}^{-1}$ with $13 \%$ standard humidity). At this site, variability in winter wheat yields due to different previous crops was not accounted for, as sugar beet was the only preceding crop every year. In the other sites, it was observed as reference winter wheat yields were matched closer with other previous crops than sugar beet (sorghum at Papiano di Marsciano, tomato at Ravenna).

Manipulation of $\mathrm{N}$ supply across site-year combinations had a fairly small influence on mean grain yield. The high-input conditions applied at Ravenna resulted in higher mean grain yields ranging from $+1.4 \%$ to $+3.4 \%$ for cultivar Bolero; and from +1.6 to $+4.4 \%$ for cultivar Pascal. The higher nitrogen regimes applied at Papiano di Marsciano resulted in mean grain yields lower than those at Ravenna (from +1.1 to $+3.4 \%$ for cultivar Bolero; from +2.2 to $2.8 \%$ for cultivar Pascal). At San Pancrazio the grain yield variation due to high $\mathrm{N}$ inputs was moderately positive for cultivar Bolero (ranging from +0.6 to $+3.1 \%$ ), though negative for cultivar Pascal (ranging from $-3.3 \%$ to $-3.8 \%$ ). Such unexpected negative variations are compatible with the variability registered in the data, i.e. standard error of $123.3 \mathrm{~kg} \mathrm{ha}^{-1}$ at Papiano di 
Table 4. Nitrogen rates $\left(\mathrm{kg} \mathrm{ha}^{-1}\right)$ applied in the long-term simulation study with Disciplinare Produzione Integrata (DPI) and CropSyst (CS) options at three sites and three rotations (mean and standard error). Standard errors between brackets refer to CS computations.

\begin{tabular}{|c|c|c|}
\hline \multirow[t]{2}{*}{ Rotation } & \multicolumn{2}{|c|}{ DPI, CS } \\
\hline & N1 & $\mathrm{N} 2, \mathrm{~N} 3$ \\
\hline & \multicolumn{2}{|c|}{ Papiano di Marsciano } \\
\hline sb-ww & $79 \pm 0.9( \pm 1.9)$ & $129 \pm 0.9( \pm 1.9)$ \\
\hline sb-ww-p-ww & $74 \pm 0.8( \pm 2.3)$ & $124 \pm 0.8( \pm 2.4)$ \\
\hline \multirow[t]{2}{*}{ sf-ww } & $129 \pm 0.9( \pm 2.5)$ & $179 \pm 0.9( \pm 3.4)$ \\
\hline & \multicolumn{2}{|c|}{ Ravenna } \\
\hline sb-ww & $87 \pm 1.4( \pm 1.8)$ & $137 \pm 1.4( \pm 1.8)$ \\
\hline sb-ww-p-ww & $82 \pm 1.2( \pm 2.0)$ & $132 \pm 1.2( \pm 2.0)$ \\
\hline \multirow{2}{*}{ sf-ww } & $137 \pm 1.4( \pm 2.4)$ & $187 \pm 1.4( \pm 2.8)$ \\
\hline & \multicolumn{2}{|c|}{ San Pancrazio } \\
\hline sb-ww & $100 \pm 1.0( \pm 2.1)$ & $150 \pm 1.0( \pm 2.3)$ \\
\hline sb-ww-p-ww & $95 \pm 0.8( \pm 1.6)$ & $145 \pm 0.8( \pm 1.6)$ \\
\hline sf-ww & $150 \pm 1.0( \pm 2.2)$ & $200 \pm 2.2( \pm 3.6)$ \\
\hline
\end{tabular}

Marsciano, $242.2 \mathrm{~kg} \mathrm{ha}^{-1}$ at Ravenna, $174.4 \mathrm{~kg}$ $\mathrm{ha}^{-1}$ at San Pancrazio.

The agreement between model outputs and field data was evaluated by the inspection of time series graphs. Typical 1-year simulated cycles, starting with emergence, for above ground crop biomass and plant nitrogen concentration at Papiano di Marsciano are published through the site http://www.sipeaa.it/sic. Similar results were obtained at Ravenna and San Pancrazio (unpublished). A unique set of parameters was used to model both cultivars because a clear difference in the crop outputs was not observed.

Table 5. Rainfall (mm) in the winter wheat growing season and fallow periods from the long-term simulation study at three sites and three rotations (mean and standard error).

\begin{tabular}{llc}
\hline Rotation & Season & Fallow \\
\hline \multicolumn{3}{c}{ Papiano di Marsciano } \\
\hline sb-ww & $479 \pm 14.7$ & $190 \pm 14.5$ \\
sb-ww-p-ww & $474 \pm 10.5$ & $213 \pm 10.6$ \\
sf-ww & $479 \pm 14.7$ & $240 \pm 14.5$ \\
\hline \multicolumn{3}{c}{ Ravenna } \\
\hline sb-ww & $418 \pm 11.2$ & $151 \pm 11.6$ \\
sb-ww-p-ww & $413 \pm 8.1$ & $180 \pm 11.6$ \\
sf-ww & $418 \pm 11.2$ & $210 \pm 12.0$ \\
\hline \multicolumn{2}{c}{ San Pancrazio } \\
\hline sb-ww & $491 \pm 13.7$ & $191 \pm 13.6$ \\
sb-ww-p-ww & $487 \pm 9.6$ & $210 \pm 9.8$ \\
sf-ww & $491 \pm 13.7$ & $231 \pm 13.0$ \\
\hline
\end{tabular}

\subsection{Long-term simulation study}

3.2.1 Nitrogen application rates. Table 4 reports $\mathrm{N}$ rates applied to winter wheat, averaged across the simulated years at three sites. Larger spreading of CS N amounts is apparent from the higher standard errors, showing major sensitivity to weather variability of a physically-based model accounting for run-time soil $\mathrm{N}$ conditions than an empirical model. At Ravenna, to take the best example, CS N1 rates for winter wheat in the rotation sb-ww-p-ww ranged from 16 to 113 $\mathrm{kg} \mathrm{ha}{ }^{-1}$, compared to a range of 58 to $97 \mathrm{~kg} \mathrm{ha}^{-1}$ with DPI N1.

In addition to fertilization, mineralization was the only other source of $\mathrm{N}$ addition considered in this study. Simulated $\mathrm{N}$ mineralization fluctuated between 15 and $60 \mathrm{~kg} \mathrm{~N} \mathrm{ha}^{-1} \mathrm{yr}^{-1}$, with no significant variation across fertilization treatments and rotations. Extreme values (about $60 \mathrm{~kg} \mathrm{ha}^{-1} \mathrm{yr}^{-1}$ ) were registered at San Pancrazio.

3.2.2 Soil water balance. Rainfall (Table 5) and evapotranspiration (Table 6) were by far the largest components of the soil water balance. Season precipitation (data not shown) presented a large year-to-year variability, fluctuating between 341 and $594 \mathrm{~mm}$ at Papiano di Marsciano, 361 and $696 \mathrm{~mm}$ at San Pancrazio, 290 and $516 \mathrm{~mm}$ at Ravenna. Actual evapotranspiration during the crop growth periods (data not shown) presented a large year-to-year variability as well (Papiano di Marsciano: 292742 mm; Ravenna: 254-571 mm; San Pancrazio: $343-457 \mathrm{~mm}$ ) and did not vary significantly across rotations or fertilization treatments. Evapotranspiration during no crop periods, mostly due to evaporation from soil and residues, was relatively low (16-31\% of season evapotranspiration). The ratio between precipitation and actual evapotranspiration for crop periods (winter and spring) tended to be around 1 at all sites, fluctuating from 0.8 up to 1.5. During no crop periods (essentially summer and fall), the average ratio between precipitation and actual evapotranspiration was always larger than 1, with maximum values observed at San Pancrazio (up to 4.4 with sb-ww-p-ww, corresponding to excess water of about $240 \mathrm{~mm}$ ). Some of the excess water became unavailable for the crop and reached the bottom of the soil profile. As a consequence of that, soil water 
Table 6. Actual evapotranspiration $(\mathrm{mm})$ in the winter wheat growing season and fallow periods from the long-term simulation study with Disciplinare Produzione Integrata (DPI), CropSyst (CS) and conventional (T) options at three sites and three rotations (mean and standard error).

\begin{tabular}{|c|c|c|c|c|c|c|c|c|c|c|c|c|c|c|}
\hline \multirow[t]{3}{*}{ Rotation } & \multicolumn{5}{|c|}{ DPI } & \multicolumn{7}{|c|}{$\mathrm{CS}$} & \multirow{2}{*}{\multicolumn{2}{|c|}{$\mathrm{T}$}} \\
\hline & \multirow{2}{*}{$\frac{\mathrm{N} 1}{\text { Season }}$} & \multicolumn{3}{|c|}{$\mathrm{N} 2$} & \multirow{2}{*}{$\begin{array}{c}\text { N3 } \\
\text { Season }\end{array}$} & \multicolumn{3}{|c|}{ N1 } & \multirow{2}{*}{$\frac{\text { N2 }}{\text { Season }}$} & \multicolumn{3}{|c|}{ N3 } & & \\
\hline & & Fallow & Season & Fallow & & Fallow & Season & Fallow & & Fallow & Season & Fallow & Season & Fallow \\
\hline \multicolumn{15}{|c|}{ Papiano di Marsciano } \\
\hline sb-ww & $452 \pm 8.5$ & $96 \pm 8.4$ & $451 \pm 8.5$ & $95 \pm 8.4$ & $451 \pm 8.5$ & $95 \pm 8.4$ & $458 \pm 8.4$ & $94 \pm 8.4$ & $457 \pm 8.4$ & $94 \pm 8.4$ & $457 \pm 8.4$ & $94 \pm 8.4$ & $449 \pm 8.8$ & $94 \pm 8.4$ \\
\hline sb-ww-p-ww & $453 \pm 5.7$ & $123 \pm 6.7$ & $452 \pm 5.8$ & $129 \pm 7.6$ & $453 \pm 5.7$ & $123 \pm 6.7$ & $460 \pm 5.7$ & $122 \pm 6.7$ & $459 \pm 5.7$ & $122 \pm 6.7$ & $459 \pm 5.7$ & $122 \pm 6.7$ & $453 \pm 5.7$ & $123 \pm 6.7$ \\
\hline sf-ww & $451 \pm 8.5$ & $138 \pm 8.1$ & $451 \pm 8.5$ & $138 \pm 8.1$ & $451 \pm 8.5$ & $138 \pm 8.1$ & $457 \pm 8.4$ & $138 \pm 8.1$ & $457 \pm 8.4$ & $138 \pm 8.1$ & $457 \pm 8.4$ & $138 \pm 8.1$ & $449 \pm 8.8$ & $137 \pm 8.2$ \\
\hline \multicolumn{15}{|c|}{ Ravenna } \\
\hline sb-ww & $423 \pm 8.4$ & $81 \pm 7.4$ & $423 \pm 8.5$ & $81 \pm 7.4$ & $423 \pm 6.5$ & $81 \pm 7.4$ & $430 \pm 8.7$ & $80 \pm 7.4$ & $430 \pm 8.8$ & $80 \pm 7.4$ & $430 \pm 8.8$ & $80 \pm 7.4$ & $420 \pm 8.9$ & $80 \pm 7.5$ \\
\hline sb-ww-p-ww & $432 \pm 5.8$ & $112 \pm 6.2$ & $433 \pm 5.5$ & $114 \pm 6.9$ & $432 \pm 5.8$ & $112 \pm 6.2$ & $439 \pm 6.3$ & $111 \pm 6.3$ & $438 \pm 6.3$ & $111 \pm 6.3$ & $439 \pm 6.3$ & $111 \pm 6.3$ & $432 \pm 5.8$ & $112 \pm 6.2$ \\
\hline sf-ww & $425 \pm 8.1$ & $129 \pm 7.6$ & $425 \pm 8.1$ & $129 \pm 7.6$ & $425 \pm 8.1$ & $129 \pm 7.6$ & $431 \pm 8.5$ & $128 \pm 7.6$ & $431 \pm 8.5$ & $128 \pm 7.6$ & $431 \pm 8.5$ & $128 \pm 7.6$ & $421 \pm 8.5$ & $127 \pm 7.7$ \\
\hline \multicolumn{15}{|c|}{ San Pancrazio } \\
\hline sb-ww & $446 \pm 7.3$ & $74 \pm 7.6$ & $446 \pm 7.3$ & $74 \pm 7.6$ & $446 \pm 7.3$ & $74 \pm 7.6$ & $455 \pm 7.9$ & $73 \pm 7.6$ & $455 \pm 7.9$ & $73 \pm 7.6$ & $455 \pm 7.9$ & $73 \pm 7.6$ & $443 \pm 7.5$ & $73 \pm 7.6$ \\
\hline sb-ww-p-ww & $446 \pm 5.3$ & $100 \pm 6.1$ & $446 \pm 5.3$ & $103 \pm 6.8$ & $446 \pm 5.3$ & $100 \pm 6.1$ & $455 \pm 5.7$ & $99 \pm 6.1$ & $455 \pm 5.7$ & $99 \pm 6.1$ & $455 \pm 5.7$ & $99 \pm 6.1$ & $446 \pm 5.3$ & $100 \pm 6.1$ \\
\hline sf-ww & $447 \pm 7.3$ & $111 \pm 7.4$ & $447 \pm 7.3$ & $111 \pm 7.4$ & $447 \pm 7.3$ & $111 \pm 7.4$ & $456 \pm 7.9$ & $111 \pm 7.4$ & $456 \pm 7.9$ & $111 \pm 7.4$ & $456 \pm 7.9$ & $111 \pm 7.4$ & $444 \pm 7.6$ & $110 \pm 7.5$ \\
\hline
\end{tabular}

drainage was also a substantial component of the water balance, providing vehicle to possible $\mathrm{N}$ leaching. Major sensitivity to water percolation was associated to the presence of potato in the rotation at all sites, markedly at San Pancrazio (about $160 \mathrm{~mm}$ each year, up to almost $500 \mathrm{~mm}$ ).

3.2.3 Crop yield. Average long-term simulation yields for winter wheat are shown in Table 7. Grain yields with $\mathrm{N} 1$ were in general larger than reference values for the sites, because possible stress factors are not fully accounted for by the simulation.
Little effect of N2 and N3 levels on yields was observed, compared to $\mathrm{N} 1(+10 \%$ or less with DPI; $+7.5 \%$ or less with CS). Increases were more remarkable at Papiano di Marsciano with sb-ww. In general, crop yields increased by $3.5-4 \%$ or less when CS rather than DPI rules were applied. Figure 4 shows the expected mean yields and mean variances associated with the fertilization and rotation management at the three locations, according to both DPI and CS rules. At low mean yields (about $6000 \mathrm{~kg} \mathrm{ha}^{-1}$ ), mean variances are expected to be high with all rotations. This is depicted by the results from

Table 7. Winter wheat grain yield $\left(\mathrm{kg} \mathrm{ha}^{-1}\right)$ from the long-term simulation study with Disciplinare Produzione Integrata (DPI), CropSyst (CS) and conventional (T) options at three sites and three rotations (mean and standard error).

\begin{tabular}{|c|c|c|c|c|c|c|c|}
\hline \multirow[t]{2}{*}{ Rotation } & \multicolumn{3}{|c|}{ DPI } & \multicolumn{3}{|c|}{$\mathrm{CS}$} & \multirow{2}{*}{$\mathrm{T}$} \\
\hline & N1 & $\mathrm{N} 2$ & N3 & N1 & $\mathrm{N} 2$ & N3 & \\
\hline \multicolumn{8}{|c|}{ Papiano di Marsciano } \\
\hline sb-ww & $5761 \pm 240.9$ & $6325 \pm 290.3$ & $6323 \pm 291.3$ & $5967 \pm 246.3$ & $6412 \pm 291.6$ & $6415 \pm 292.0$ & $6355 \pm 296.7$ \\
\hline sb-ww-p-ww & $6253 \pm 187.4$ & $6454 \pm 194.8$ & $6455 \pm 195.2$ & $6329 \pm 182.7$ & $6500 \pm 195.2$ & $6500 \pm 195.2$ & $6466 \pm 196.6$ \\
\hline sf-ww & $6286 \pm 293.2$ & $6300 \pm 297.5$ & $6303 \pm 296.5$ & $6352 \pm 293.8$ & $6344 \pm 294.8$ & $6344 \pm 294.8$ & $6298 \pm 297.1$ \\
\hline \multicolumn{8}{|c|}{ Ravenna } \\
\hline sb-ww & $6648 \pm 178.2$ & $7094 \pm 198.4$ & $7093 \pm 198.1$ & $6806 \pm 164.2$ & $7232 \pm 192.0$ & $7233 \pm 192.2$ & $7099 \pm 201.2$ \\
\hline sb-ww-p-ww & $7234 \pm 126.1$ & $7372 \pm 127.4$ & $7372 \pm 127.4$ & $7340 \pm 123.0$ & $7418 \pm 127.8$ & $7419 \pm 127.8$ & $7371 \pm 127.7$ \\
\hline sf-ww & $7151 \pm 184.8$ & $7141 \pm 184.9$ & $7147 \pm 184.8$ & $7215 \pm 182.5$ & $7161 \pm 184.7$ & $7163 \pm 184.6$ & $7139 \pm 185.2$ \\
\hline \multicolumn{8}{|c|}{ San Pancrazio } \\
\hline sb-ww & $6906 \pm 127.9$ & $7042 \pm 137.3$ & $7044 \pm 137.2$ & $7050 \pm 136.1$ & $7070 \pm 136.4$ & $7070 \pm 136.4$ & $7042 \pm 137.4$ \\
\hline sb-ww-p-ww & $7043 \pm 67.5$ & $7068 \pm 68.2$ & $7068 \pm 68.2$ & $7090 \pm 67.6$ & $7092 \pm 67.7$ & $7092 \pm 67.7$ & $7069 \pm 68.1$ \\
\hline sf-ww & $7033 \pm 138.8$ & $7031 \pm 138.8$ & $7029 \pm 139.0$ & $7055 \pm 138.3$ & $7055 \pm 138.3$ & $7056 \pm 138.2$ & $7030 \pm 139.1$ \\
\hline
\end{tabular}



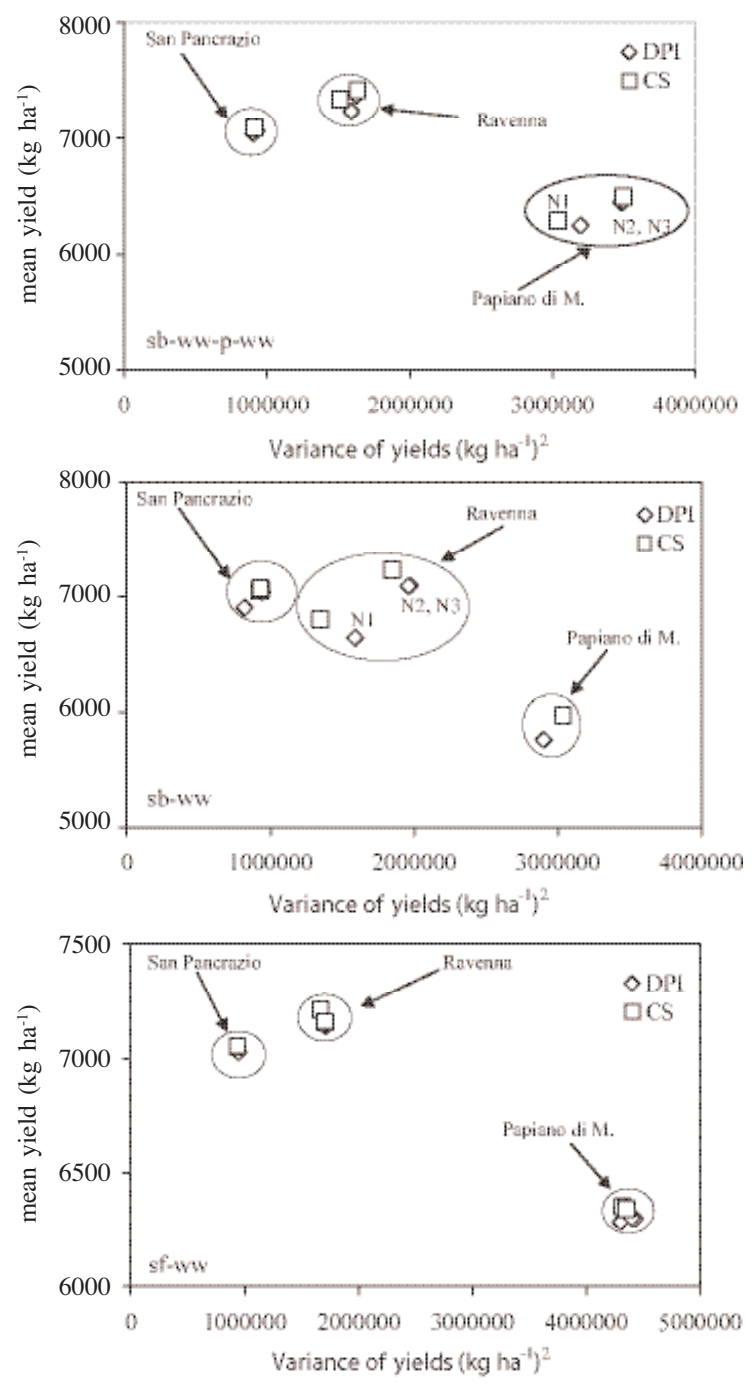

Figure 4. Simulated winter wheat yield: mean-variance plot for different locations, rotations, and nitrogen rates.

Papiano di Marsciano. Simulated yield was observed to increase with less variability at higher latitudes, little effect being related to alternative $\mathrm{N}$ rates or rules.

\subsubsection{Nitrogen uptake and nitrogen use efficiency.} Average values of crop nitrogen uptake (Nup) were summarized in Table 8 . Nup considers here above ground and root fractions. For winter wheat $\mathrm{N}$ uptake, the DPI references indicate $\mathrm{N}$ concentration of $0.6 \%$ in the straw and $1.98 \%$ in the grain. For $6500 \mathrm{~kg} \mathrm{ha}^{-1}$ grain yield (13000 $\mathrm{kg} \mathrm{ha}^{-1}$ above ground biomass at harvest), for example, these concentrations correspond to an uptake of $133 \mathrm{~kg} \mathrm{ha}^{-1}$ (harvest index of 0.50 , roots not included), which compares well with the simulated values (including roots).

$\mathrm{N}$ content in the biomass increased with increasing $\mathrm{N}$ fertilization to a fairly similar extent in the three sites. At Ravenna and San Pancrazio, Nup considerably increased in average between $\mathrm{N} 1$ and N2/N3 with rotations including sugar beet. For instance, $+30 \%$ was observed at Ravenna and Papiano di Marsciano and $+20 \%$ at San Pancrazio with sb-ww, although yields increased by only $6-7 \%$ or less, indicating larger plant $\mathrm{N}$ concentration for higher $\mathrm{N}$ rates. Conventional rates gave at times large increases of Nup, compared to N1 rates, especially at Ravenna with sb-ww, almost $+50 \%$, while yield increases were of about 4-7\%. CS-based fertilization produced a generalized increase in Nup (by $5 \%$ or less), compared to DPI rules. At San Pancrazio, small or null increase of Nup observed with $\mathrm{N} 2$ and $\mathrm{N} 3$ under rotation sf-ww suggests additional $\mathrm{N}$ amount to $\mathrm{N} 1$ rates is not requested to satisfy crop requirements. A similar outcome emerged at Ravenna with CS only.

Physiological $\mathrm{N}$ use efficiency (NUEp, Noulas, 2002), i.e. the ratio of grain yield to total $\mathrm{N}$ uptake $\left(\mathrm{kg} \mathrm{kg}^{-1}\right)$, was found different for different locations and fertilization methods. The general (though irregular) trend for NUEp was to decrease as $\mathrm{N}$ uptake increases. Lower values of NUEp were registered at Papiano di Marsciano (23-32 kg kg-1), followed by San Pancrazio (33-40 $\mathrm{kg} \mathrm{kg}^{-1}$ ) and Ravenna (34-42 $\mathrm{kg} \mathrm{kg}^{-1}$ ). Table 9 shows the average ratios of fertilizer $\mathrm{N}$ applied to $\mathrm{N}$ uptake (NUEu: uptake nitrogen use efficiency, Novoa and Loomis, 1981). In average, the applied $\mathrm{N}$ is below the $\mathrm{N}$ uptake requirements in almost all cases (ratio lower than 1). N supplies at San Pancrazio only tended to be equal to crop requirements in a few cases (CS option, rates N1 and N2 with sf-ww, and conventional treatment with sb-ww and sf-ww). The agronomic efficiency of N use (NUEa: grain yield per unit of $\mathrm{N}$ applied, Christianson and Vlek, 1991) tended to linearly decrease with $\mathrm{N}$ applied (Figure 5). Lower $r^{2}$ values with CS data at Ravenna and San Pancrazio were mainly attributed to one point with N1, always greater than the analogous DPI point, indicating major efficiency with CS at low rates.

3.2.5 Nitrogen leaching. Table 10 shows the longterm yearly average of annual $\mathrm{N}$ leaching for 
Table 8. Winter wheat nitrogen uptake $\left(\mathrm{kg} \mathrm{ha}^{-1}\right)$ from the long-term simulation study with Disciplinare Produzione Integrata (DPI), CropSyst (CS) and conventional (T) options at three sites and three rotations (mean and standard error).

\begin{tabular}{|c|c|c|c|c|c|c|c|}
\hline \multirow[t]{2}{*}{ Rotation } & \multicolumn{3}{|c|}{ DPI } & \multicolumn{3}{|c|}{$\mathrm{CS}$} & \multirow{2}{*}{$\mathrm{T}$} \\
\hline & N1 & $\mathrm{N} 2$ & N3 & N1 & $\mathrm{N} 2$ & N3 & \\
\hline \multicolumn{8}{|c|}{ Papiano di Marsciano } \\
\hline sb-ww & $155 \pm 3.0$ & $203 \pm 2.6$ & $204 \pm 2.6$ & $158 \pm 2.1$ & $207 \pm 2.0$ & $208 \pm 2.0$ & $247 \pm 2.7$ \\
\hline sb-ww-p-ww & $193 \pm 4.3$ & $231 \pm 2.8$ & $232 \pm 2.8$ & $203 \pm 4.3$ & $238 \pm 2.0$ & $238 \pm 2.0$ & $247 \pm 1.8$ \\
\hline sf-ww & $213 \pm 2.7$ & $244 \pm 2.2$ & $243 \pm 2.3$ & $220 \pm 2.0$ & $247 \pm 2.5$ & $247 \pm 2.5$ & $246 \pm 2.7$ \\
\hline \multicolumn{8}{|c|}{ Ravenna } \\
\hline sb-ww & $155 \pm 10.5$ & $202 \pm 7.8$ & $202 \pm 7.8$ & $156 \pm 8.7$ & $205 \pm 6.3$ & $205 \pm 6.2$ & $231 \pm 7.7$ \\
\hline sb-ww-p-ww & $200 \pm 4.1$ & $233 \pm 4.1$ & $233 \pm 4.1$ & $206 \pm 3.6$ & $234 \pm 1.8$ & $234 \pm 1.8$ & $235 \pm 1.9$ \\
\hline sf-ww & $223 \pm 6.6$ & $234 \pm 5.9$ & $234 \pm 5.9$ & $231 \pm 5.3$ & $234 \pm 5.9$ & $234 \pm 5.9$ & $232 \pm 6.5$ \\
\hline \multicolumn{8}{|c|}{ San Pancrazio } \\
\hline sb-ww & $174 \pm 3.2$ & $208 \pm 1.6$ & $208 \pm 1.6$ & $178 \pm 2.0$ & $214 \pm 1.5$ & $214 \pm 1.5$ & $216 \pm 2.0$ \\
\hline sb-ww-p-ww & $206 \pm 7.4$ & $216 \pm 4.4$ & $216 \pm 4.4$ & $215 \pm 4.8$ & $217 \pm 4.4$ & $217 \pm 4.4$ & $217 \pm 4.4$ \\
\hline sf-ww & $215 \pm 1.9$ & $217 \pm 2.0$ & $217 \pm 2.0$ & $217 \pm 2.0$ & $217 \pm 2.0$ & $217 \pm 2.0$ & $216 \pm 2.0$ \\
\hline
\end{tabular}

Table 9. Winter wheat uptake nitrogen use efficiency $\left(\mathrm{kg} \mathrm{kg}^{-1}\right)$ from the long-term simulation study with Disciplinare Produzione Integrata (DPI), CropSyst (CS) and conventional (T) options at three sites and three rotations (mean and standard error).

\begin{tabular}{|c|c|c|c|c|c|c|c|}
\hline \multirow[t]{2}{*}{ Rotation } & \multicolumn{3}{|c|}{ DPI } & \multicolumn{3}{|c|}{$\mathrm{CS}$} & \multirow{2}{*}{$\mathrm{T}$} \\
\hline & $\mathrm{N} 1$ & $\mathrm{~N} 2$ & N3 & N1 & $\mathrm{N} 2$ & N3 & \\
\hline \multicolumn{8}{|c|}{ Papiano di Marsciano } \\
\hline sb-ww & $0.5 \pm \sim 0.0$ & $0.6 \pm \sim 0.0$ & $0.6 \pm \sim 0.0$ & $0.5 \pm \sim 0.0$ & $0.6 \pm \sim 0.0$ & $0.6 \pm \sim 0.0$ & $0.9 \pm \sim 0.0$ \\
\hline sb-ww-p-ww & $0.4 \pm \sim 0.0$ & $0.6 \pm \sim 0.0$ & $0.5 \pm \sim 0.0$ & $0.4 \pm \sim 0.0$ & $0.5 \pm \sim 0.0$ & $0.5 \pm \sim 0.0$ & $0.6 \pm \sim 0.0$ \\
\hline sf-ww & $0.6 \pm \sim 0.0$ & $0.7 \pm \sim 0.0$ & $0.7 \pm \sim 0.0$ & $0.6 \pm \sim 0.0$ & $0.7 \pm \sim 0.0$ & $0.7 \pm \sim 0.0$ & $0.9 \pm \sim 0.0$ \\
\hline \multicolumn{8}{|c|}{ Ravenna } \\
\hline sb-ww & $0.6 \pm \sim 0.0$ & $0.7 \pm \sim 0.0$ & $0.7 \pm \sim 0.0$ & $0.6 \pm \sim 0.0$ & $0.7 \pm \sim 0.0$ & $0.7 \pm \sim 0.0$ & $1.0 \pm \sim 0.0$ \\
\hline sb-ww-p-ww & $0.6 \pm \sim 0.0$ & $0.6 \pm \sim 0.0$ & $0.4 \pm \sim 0.0$ & $0.6 \pm \sim 0.0$ & $0.6 \pm \sim 0.0$ & $0.6 \pm \sim 0.0$ & $0.6 \pm \sim 0.0$ \\
\hline sf-ww & $0.6 \pm \sim 0.0$ & $0.8 \pm \sim 0.0$ & $0.8 \pm \sim 0.0$ & $0.6 \pm \sim 0.0$ & $0.8 \pm \sim 0.0$ & $0.8 \pm \sim 0.0$ & $1.0 \pm \sim 0.0$ \\
\hline \multicolumn{8}{|c|}{ San Pancrazio } \\
\hline sb-ww & $0.6 \pm \sim 0.0$ & $0.7 \pm \sim 0.0$ & $0.7 \pm \sim 0.0$ & $0.6 \pm \sim 0.0$ & $0.7 \pm \sim 0.0$ & $0.7 \pm \sim 0.01$ & $1.0 \pm \sim 0.0$ \\
\hline sb-ww-p-ww & $0.5 \pm \sim 0.0$ & $0.7 \pm \sim 0.0$ & $0.7 \pm \sim 0.0$ & $0.5 \pm \sim 0.0$ & $0.7 \pm \sim 0.0$ & $0.7 \pm \sim 0.0$ & $0.7 \pm \sim 0.0$ \\
\hline sf-ww & $0.7 \pm \sim 0.0$ & $0.9 \pm \sim 0.0$ & $0.9 \pm \sim 0.0$ & $0.7 \pm \sim 0.0$ & $1.0 \pm \sim 0.0$ & $1.0 \pm \sim 0.0$ & $1.0 \pm \sim 0.0$ \\
\hline
\end{tabular}

winter wheat crops in all of the rotations and fertilization options considered.

Average values from DPI did not appear different from CS-based values and both were low in many cases, while the T option tended to give important nitrogen leaching at all sites. Under $\mathrm{T}$ rates, winter wheat in the rotation sb-ww-pww had in particular the most potential for annual $\mathrm{N}$ leaching, which was the maximum at San Pancrazio (above $50 \mathrm{~kg} \mathrm{ha}^{-1}$ in average, up to $190 \mathrm{~kg} \mathrm{ha}^{-1}$ ). When DPI and CS rules were applied, winter wheat in the rotation including sunflower had the most potential for annual $\mathrm{N}$ leaching, maximum at San Pancrazio with N2 and N3 (about 30-40 $\mathrm{kg} \mathrm{ha}^{-1}$ in average, up to $120 \mathrm{~kg} \mathrm{ha}^{-1}$ ). At this site, CS options N2 and N3 tended to be similar to $\mathrm{T}$ rate with the rotation sf-ww (average values), because $\mathrm{N}$ provided was higher than required, as suggested by crop $\mathrm{N}$ uptake values which did not increase with N2 and N3 (Table 9). Probability distributions (selected graphs in Figure 6) were different for different rotations, but largely similar in the shape across different sites. Conventional strategy was dominant in all cases, as its probability line fully lies to the right of other strategies.

Figure 7 shows the expected mean $\mathrm{N}$ leaching and mean variances associated to the fertil- 
Bellocchi G., Donatelli M., Monotti M., Carnevali G., Corbellini M., Scudellari D.
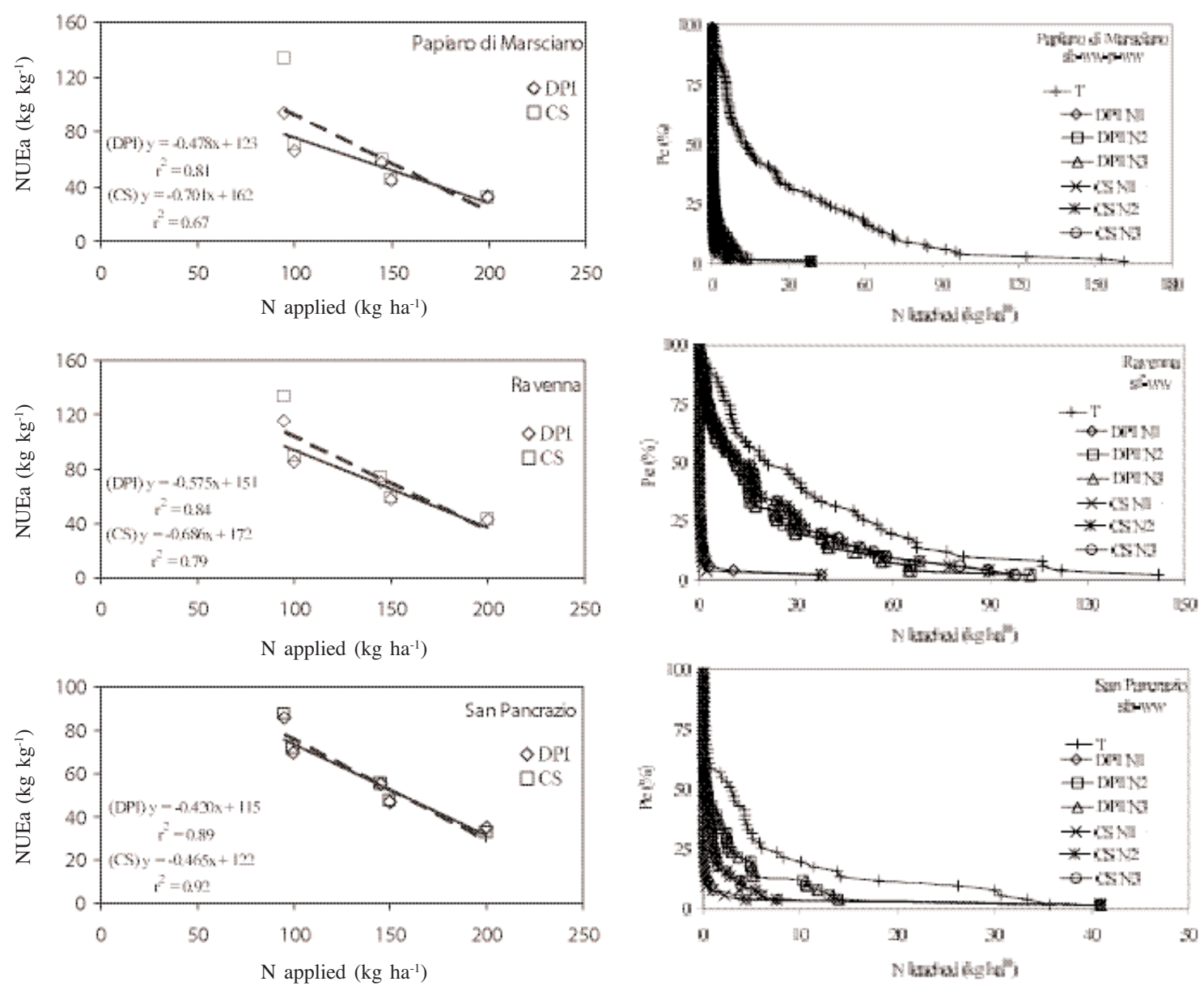

Figure 5. Simulated agronomic nitrogen use efficiency (NUEa)-nitrogen applied plot and regression lines for different locations and nitrogen rates (average across rotations).

Figure 6. Simulated nitrogen leached with DPI, CS, and T options: probability of exceedence (Pe) distribution curves for three sites at selected rotations.

Table 10. Annual amount of nitrogen $\left(\mathrm{kg} \mathrm{ha}^{-1}\right)$ leached from the long-term simulation study with Disciplinare Produzione Integrata (DPI), CropSyst (CS) and conventional (T) options at three sites and three rotations (mean and standard error).

\begin{tabular}{|c|c|c|c|c|c|c|c|}
\hline \multirow[t]{2}{*}{ Rotation } & \multicolumn{3}{|c|}{ DPI } & \multicolumn{3}{|c|}{$\mathrm{CS}$} & \multirow{2}{*}{$\mathrm{T}$} \\
\hline & N1 & $\mathrm{N} 2$ & N3 & N1 & N2 & N3 & \\
\hline \multicolumn{8}{|c|}{ Papiano di Marsciano } \\
\hline sb-ww & $0.8 \pm 0.8$ & $0.8 \pm 0.8$ & $0.8 \pm 0.8$ & $0.8 \pm 0.773$ & $0.8 \pm 0.8$ & $0.8 \pm 0.8$ & $2.4 \pm 0.9$ \\
\hline sb-ww-p-ww & $1.0 \pm 0.5$ & $2.1 \pm 0.6$ & $2.1 \pm 0.6$ & $1.0 \pm 0.547$ & $1.7 \pm 0.6$ & $1.6 \pm 0.6$ & $28.4 \pm 3.3$ \\
\hline sf-ww & $0.8 \pm 0.8$ & $2.3 \pm 0.9$ & $2.3 \pm 0.9$ & $0.8 \pm 0.773$ & $1.8 \pm 0.8$ & $1.8 \pm 0.8$ & $11.5 \pm 2.5$ \\
\hline \multicolumn{8}{|c|}{ Ravenna } \\
\hline sb-ww & $0.8 \pm 0.8$ & $0.8 \pm 0.8$ & $0.8 \pm 0.8$ & $0.8 \pm 0.8$ & $0.8 \pm 0.8$ & $0.8 \pm 0.8$ & $13.2 \pm 2.5$ \\
\hline sb-ww-p-ww & $1.0 \pm 0.8$ & $7.0 \pm 1.2$ & $7.1 \pm 1.2$ & $1.0 \pm 0.5$ & $8.5 \pm 1.2$ & $8.5 \pm 1.2$ & $46.6 \pm 3.9$ \\
\hline sf-ww & $1.3 \pm 0.8$ & $18.1 \pm 3.0$ & $18.2 \pm 3.0$ & $1.0 \pm 0.8$ & $20.9 \pm 3.4$ & $21.0 \pm 3.5$ & $33.6 \pm 4.7$ \\
\hline \multicolumn{8}{|c|}{ San Pancrazio } \\
\hline sb-ww & $1.1 \pm 0.8$ & $3.0 \pm 0.9$ & $3.0 \pm 0.9$ & $1.0 \pm 0.8$ & $1.8 \pm 0.8$ & $1.8 \pm 0.8$ & $6.2 \pm 1.3$ \\
\hline sb-ww-p-ww & $8.0 \pm 1.1$ & $23.2 \pm 2.2$ & $23.2 \pm 2.2$ & $7.2 \pm 0.9$ & $26.2 \pm 1.9$ & $26.2 \pm 1.9$ & $56.5 \pm 3.7$ \\
\hline sf-ww & $10.8 \pm 2.1$ & $28.6 \pm 3.6$ & $28.6 \pm 3.6$ & $10.7 \pm 1.8$ & $38.9 \pm 3.8$ & $38.9 \pm 3.7$ & $37.4 \pm 4.1$ \\
\hline
\end{tabular}


ization and rotation management explored at three sites, according to both DPI and CS. Introduction of potato (middle graph) or sunflower (bottom graph) increases the level of $\mathrm{N}$ leaching and mean variance (level of the risk) at Ravenna and San Pancrazio.

\section{Discussion}

Management practices and weather variability were the most important factors in determining the potential for grain yield and $\mathrm{N}$ leaching from the simulated winter wheat systems. Grain yields suggest modest increases are achieved with improved protocols derived from the balance-sheet method, and further increase with CS options rather than DPI-based fertilization rules is also expected. Both CS and DPI techniques appeared beneficial when compared to the conventional practice.

Soil water drainage and $\mathrm{N}$ leached from this simulation study compare well with the estimates given by Donatelli et al. (1999) from CropSyst simulations on alternative cropping systems (including winter wheat) in Emilia-Romagna. Acutis at al. (2000) report average N leaching estimates for Western Po valley, which are similar to the ones estimated here (7.0 to 79 $\mathrm{kg} \mathrm{ha}^{-1} \mathrm{yr}^{-1}$ as $\mathrm{NO}_{3}-\mathrm{N}$ from rainfed maize and ryegrass-maize systems on loam soils, $\mathrm{N}$ fertilization in the range $200-450 \mathrm{~kg} \mathrm{ha}^{-1}$ ). It emerges from the $\mathrm{N}$ budget that changes in the uptake $\mathrm{N}$ efficiency (Table 9) are at times determined from variations in the fertilizer $\mathrm{N}$ inputs only, and it is convenient not to increase $\mathrm{N}$ amounts where $\mathrm{N}$ uptake values does not increase in that order. This was particularly clear at San Pancrazio with sunflower in the rotation (Table 8), and generated large amounts of $\mathrm{N}$ available for leaching (Table 10). The sunflower season appeared to be the principal contributor to $\mathrm{N}$ leaching at all sites, mainly at San Pancrazio. At this site, large contents of soil organic matter in the upper layers (Table 1) also tend to give important amounts of $\mathrm{N}$ through mineralization, available for leaching (up to $60 \mathrm{~kg} \mathrm{ha}^{-1}$ of mineralized $\mathrm{N}$, against peaks of $50 \mathrm{~kg} \mathrm{ha}^{-1}$ for the other sites). Sunflower is assumed by DPI to provide null effect as residual $\mathrm{N}$, thus imposing large amounts of fertilizer $\mathrm{N}$ for the subsequent winter wheat. An important advice from this simulation study is that DPI computation is
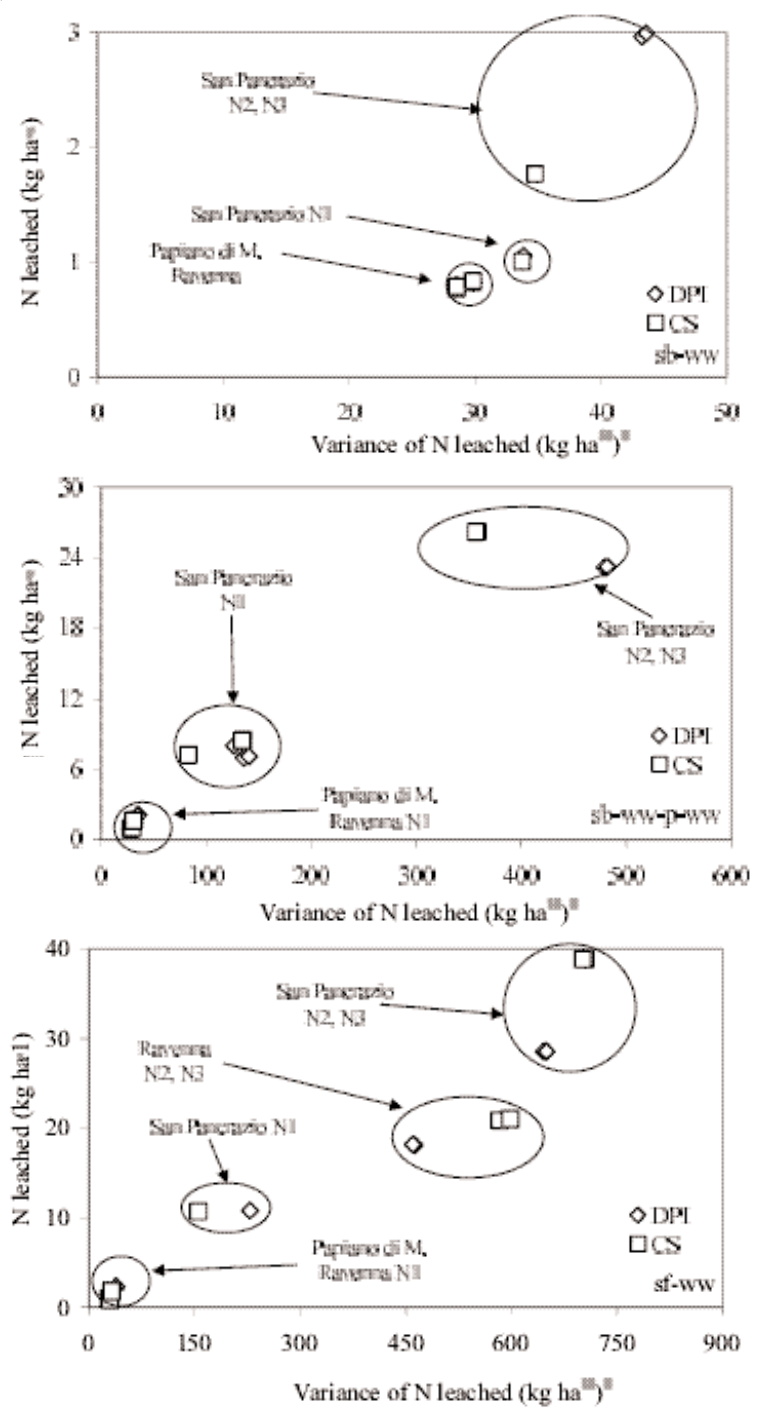

Figure 7. Simulated nitrogen leached: mean-variance plot for different locations, rotations, and nitrogen rates.

worth being reconsidered at San Pancrazio, even determining more carefully the target yield (now equal to $6020 \mathrm{~kg} \mathrm{ha}^{-1}$, the same as Ravenna). The average amounts of $\mathrm{N}$ leached are fairly small and, with the partial exception of San Pancrazio, below the average value of $23 \mathrm{~kg} \mathrm{ha}^{-1}$ $\mathrm{yr}^{-1}$ identified by OECD (1972) for arable lands by $100 \mathrm{~kg} \mathrm{ha}^{-1}$ fertilizer N. Philipps (2000) informs of larger values $\left(36-79 \mathrm{~kg} \mathrm{ha}^{-1} \mathrm{yr}^{-1}\right)$ for typical arable crops grown in Europe.

The results of this study show that an important decision about $\mathrm{N}$ application to winter wheat concerns the selection of fertilizer rate. A varied range of $\mathrm{N}$ management scenarios have been simulated and compared, allowing an ef- 
fective environmental risk by $\mathrm{N}$ losses from a field to be assessed using a physically-based model. These simulations contribute to a better understanding of the impact of climate variability on different fertilizer recommendations. Strategic decisions can be based upon the results of these simulations, provided that in practice a farm manager can recognise and match the actual soil type and drainage condition of the fields on which $\mathrm{N}$ application is to occur with the simulated field types.

CropSyst automatic routine for $\mathrm{N}$ fertilization allowed in general better efficiency of $\mathrm{N}$ use than DPI (according to different indices). However, although simplified, the DPI method showed good ability to meet crop $\mathrm{N}$ demand and preserve $\mathrm{N}$ balance in the soil. Minor differences were observed from a physically-based model, thus the DPI method can be proficiently used to orient $\mathrm{N}$ fertilization strategies. Such ability was substantially preserved at all sites and rotations, the perspective of little improvements being emerged for San Pancrazio only. The need to improve $\mathrm{N}$ rates from $\mathrm{N} 1$ to $\mathrm{N} 2$ or N3 did not emerge from this quantitative study on crop yield. Nonetheless, the little environmental risk associated to $\mathrm{N}$ leaching with the enhanced rates does not call to particular warnings and allows farmers to derive soil fertility management by using modified protocols of the DPI strategy. Conclusive judgements on the convenience expected from adopting modified protocols raises from grain quality analysis, varying from cultivar to cultivar as a function of $\mathrm{N}$ rates and application dates (manuscript I).

\section{Acknowledgements}

Raffaele Alberati, Mara Poli and Laura Castello, farm managers at Papiano di Marsciano, Ravenna and San Pancrazio, are acknowledged for their cooperation in the setup of the experiments. Gianpaolo Sarno of the Region Emilia-Romagna contributed with important advises in the initial development of the project.

Research actions supported by the Region Emilia-Romagna with the contribution of Region Umbria, by the project "SIC - Sperimentazione Interregionale Cereali (Frumento tenero - Verifica di strategie di fertilizzazione azotata)" (http://www.sipeaa.it/sic).

\section{References}

AA.VV. 2000. Disposizioni per l'applicazione della Misura $2 \mathrm{f}$ del Piano regionale di sviluppo rurale ai sensi del Reg. (CE) 1257/1999. Regione Emilia-Romagna, Assessorato Agricoltura, Ambiente e Sviluppo Sostenibile, Bologna.

Acutis M., Grignani C., Ducco G. 1998. Stochastic use of LEACHN model to forecast nitrate leaching in different maize cropping systems. Eur J. Agron., 13:191206.

Addiscott T.M., Bailey N.J., Bland G.J., Whitmore A.P. 1991. Simulation of nitrogen in soil and winter wheat crops: a management model that makes the best use of limited information. Fert. Res., 27:305-312.

Carnevali G., Sarno G. 1998. Frumento. Linee tecniche di produzione integrata. La fertilizzazione. Terra e Vita (Suppl.), 37:32-34.

Carnevali G., Sarno G., Scotti C. 2000. Il bilancio della fertilità. Il Divulgatore, 3:19-27.

Christianson C.B., Vlek P.L.G. 1991. Alleviating soil fertility constraints to food production in West Africa: efficiency of nitrogen fertilizer applied to food crops. Fert. Res., 29:21-33.

De Willigen P. 1991. Nitrogen turnover of soil-crop system; comparison of fourteen simulation models. Fert. Res., 27:141-149.

Donatelli M., Stöckle C.O. 2000. Simulation-based rules to schedule nitrogen fertilization of field crops. In: Christen O., Ordon F. (eds.): Proc. $3^{\text {rd }}$ International Crop Science Conference, 17-22 August, Hamburg, Germany, 187.

Donatelli M., Stöckle C.O., Nelson R.L., Gardi C., Bittelli M., Campbell G.S. 1999. Using the software CropSyst and ArcView in evaluating the effect of management in cropping systems in two areas of the low Po valley, Italy. Rev. de Cien. Agr., 22:87-108.

ITCF 1996. Fertilisation azotée des céréales à paille. ITCF, Paris.

Jeuffroy M.-H., Recous S., 1999. Azodyn: a simple model simulating the date of nitrogen deficiency for decision support in wheat fertilisation. Eur. J. Agron., 10:129-144.

Justes E. Mary B., Meynard J.M., Machet J.M., ThelierHuché L. 1994. Determination of a critical nitrogen dilution curve of winter wheat crops. Ann. Bot., 74:397-407.

Kerserbaum K.C., Richter J. 1991. Modelling nitrogen dynamics in a plant-soil system with a simple model for advisory purposes. Fert. Res., 27:273-282.

MacDonald A.J., Powlson D.S., Poulton P.R., Jenkinson D.S. 1989. Unused fertiliser nitrogen in arable soils its contribution to nitrate leaching. J. Sci. Food Agric., 46:407-419.

Machet J.M., Dubrulle P. 1990. Azobil: a computer program for fertiliser $\mathrm{N}$ recommendations based on a crop predictive balance sheet method. In: Scaife A. (ed.): Proc. $1^{\text {st }}$ Congress of the European Society for Agronomy, Paris, France, 21-22.

Magnickij K.P. 1973. The use of soil and plant analysis for the fertiliser recommendation development for vegetable crops. Acta Hort. (ISHS), 29:37-52. 
Meynard J.M., Cerf M., Guichard L., Jeuffroy M.-H., Makowsky D. 2002. Which decision support tools for the environmental management of nitrogen? Agronomie, 2:817-829.

Meynard J.M., Justes E., Machet J.M., Recous S. 1997. Fertilisation azotée des cultures annuelles de plein champ. In: Lemaire G., Nicolardot B. (eds.): Maitrise de l'azote dans les agrosystèmes, 183-199. INRA, Paris.

Noulas C. 2002. Parameters of nitrogen use efficiency of Swiss spring wheat genotypes (Triticum aestivum L.). $\mathrm{PhD}$ Thesis, Swiss Federal Institute of Technology, Zurich, Switzerland.

Novoa R., Loomis R.S. 1981. Nitrogen and plant production. Plant and Soil, 58:177-204.

OECD, 1972. Recommendation of the council on guiding principles concerning international economic aspects of environmental policies. May. Council Document no. C(72)128, Paris, France.

Otter-Nacke S., Kuhlmann H. 1991. A comparison of the performance of $\mathrm{N}$ simulation models in the prediction of Nmin on farmers' fields in the spring. Fert. Res., 27:341-348.

Perenzin M., Minoia C., Corbellini M. 1998. Scelta delle varietà di grano tenero. Inf. Agr. Suppl., 34:7-15.

Perenzin M., Notario T., Bertoli F., Boggini G. 2000. Scelta delle varietà. Inf. Agr. Suppl., 33: 5-14.

Perenzin M., Notario T., Boggini G. 1999. Scelta delle varietà di frumento tenero. Inf. Agr. Suppl., 34:7-16.

Philipps L. 2000. Improving organic farming techniques to reduce environmental impacts. Proc. $2^{\text {nd }} F A O$ Workshop of the Sustainable Rural Environment and Energy Network Working Group, REU Technical No. Series 63, 5-7 September 1999, Bari, Italy, 25-26.

Powlson D.S., Hart P.B.S., Poulton P.R., Johnston A.E., Jenkinson D.S. 1992. Influence of soil type, crop management and weather on the recovery of ${ }^{15} \mathrm{~N}$-labelled fertiliser applied to winter wheat in spring. J. Agric. Sci. (Camb.), 118:83-100.

Priestley C.H.B., Taylor R.J. 1972. On the assessment of surface heat flux and evaporation using large-scale parameters. Mon. Weather Rev., 100:81-82.

Recous S., Loiseau P., Machet J.M., Mary B. 1997. Transformations et devenir de l'azote de l'engrais sous cul- tures annuelles et sous prairies. In: Lemaire G., Nicolardot B. (eds.): Maîtrise de l'azote dans les agrosystèmes, 105-120. INRA, Paris, France.

Rémy J.C., Hébert J. 1977. Le devenir des engrais azotés dans le sol. CR Acad. Agric. France, 63:700-710.

Richards L.A. 1931. Capillary conduction of liquids in porous mediums. Physics, 1: 318-333.

Spiertz H.J. 2002. Resource use and sustainable cereal production. In: Villalobos F.J., Testi L. (eds.): Proc. $7^{\text {th }}$ Congress of the European Society for Agronomy, 1518 July, Cordoba, Spain, 583-584.

Steiner J.L., Howell T.A., Schneider A.D. 1991. Lysimetric evaluation of daily potential evapotranspiration models for grain sorghum. Agron. J., 83:240-247.

Stöckle C.O., Campbell G.S. 1989. Simulation of crop response to water and nitrogen: an example using spring wheat. Trans. ASAE, 32:66-74.

Stöckle C.O., Donatelli M., Nelson R. 2003. CropSyst, a cropping systems simulation model. Eur. J. Agron., 18:289-307.

Stöckle C.O., Nelson R.L., Donatelli M., Castellvì F. 2001. ClimGen: a flexible weather generation program. In: Bindi M., Donatelli M., Porter J., van Ittersum M. (eds.): Proc. $2^{\text {nd }}$ International Symposium on Modelling Cropping Systems, 16-18 July, Florence, Italy, 229-230.

Strong W.M. 1995. Nitrogen fertilisation of upland crops. In: Bacon P.E. (ed.): Nitrogen fertilisation in the environment, 129-170. Marcel Dekker, New York.

Thorup-Kristensen K. 2002. Utilising differences in rooting depth to design vegetable crop rotations with high nitrogen use efficiency (NUE). Acta Hort. (ISHS), 571:249-254.

Vanden Auweele W., Vandendriessche H. 2002. A decision support system for field vegetable crops: focus on fertilisation. Acta Hort. (ISHS), 571:149-152.

Wehrmann J., Sharpf H.-C., Kuhlmann H. 1988. The $\mathrm{N}_{\min }$ method - an aid to improve nitrogen efficiency in plant production. In: Jenkinson D.S., Smith K.A. (eds.): Nitrogen efficiency in agricultural soils, 38-45. Elsevier Applied Science, London.

Ziegler J., Strohmeier K., Brand T. 1996. Nitrogen supply of vegetables based on the "KNS-system". Acta Hort. (ISHS), 428:223-234. 